可視化情報 Vol.20 Suppl. No.1（2００００年 7月）

出海滋 ${ }^{\circ}$ 上村博 北口博司 水船栄作 (株)日立製作所 電力・電機開発研究所)

\title{
High Energy X-Ray Computed Tomography for Industrial
} Applications

\author{
Shigeru IZUMI, Hiroshi KAMIMURA, Hiroshi KITAGUCHI, Eisaku MIZUFUNE \\ ABSTRACT
}

A high energy industrial X-ray computed tomography system using silicon semiconductor detectors (Si-SSD) and electron linear accelerator (LINAC) was developed to obtain high resolution 3D images of high density and large scale object. To increase photon sensitivity, detector elements were placed parallel to the X-ray beams. The obtained sensitivity of $20 \%$ for X-ray of $3 \mathrm{MeV}$ was $3 \times 10^{4}$ times higher than that of X-ray films. It was clarified that the photon sensitivity of X-ray detectors restricts the performance of high energy X-ray CT, and it is shown that a CT image of $200 \mathrm{~mm}$ thick iron object can be obtained with $0.2 \mathrm{~mm}$ space resolution.

Keywords: X-Ray, Computed Tomography, Electron linear accelerator, Silicon semiconductor detector

\section{1. はじめに}

ディジタルエンジニアリングの発展に伴い、3D-CAD 図面からモノを造ることが一般化し、さらに3D-CAD図 面からRP(Rapid Prototyping)により自動的に立体モデ ルを造る技術も普及しつつある。一方、この逆方向の技 術(リバースエンジニアリリグ)、つまりモノからCAD図面ないしは レプリカを造る技術、あるいはCAD図面とそれに基づい て造ったモノとを照合する技術に対する必要性が増して いる。これに応える技術が三次元計測技術である。三次 元形状を計測する手段は多数あるが、その多くは表面形 状に限られる。内部の形状を正確に計測する最も有効な 手段はX線CTである。X線CTは試料内部の密度の三次元 分布を求めることができ、したがって形状の計測が可能 になる。X線CTは医療用の検査手段としてほぼ成熟した 技術になっているが、これをそのまま産業用として用い るには性能上の問題点が多数ある。とくに空間分解能が 十分でないことと高密度で大型の試料の撮影が困難な点 である。X線が最大の透過力をもつエネルギーは、物質に よって多少異なるが、およそ数 $\mathrm{MeV}$ から十数 $\mathrm{MeV}$ の間に ある。透過力が強いことは、材料内での減衰が少ないこ とであり、厚い試料のX線検査ができることになる。たと えば鉄に対するX線の透過力は約 $9 \mathrm{MeV} て ゙$ 最大になり、厚 さ $10 \mathrm{~cm}$ を透過したとき約 $1 / 10 に$ 減衰する。したがって鉄 のように高密度でしかも厚い材料を撮影対象とする場合 はこのエネルギー領域のX線を利用することで良好な画 質が得られる。このエネルギ一領域のX線源にはLINAC (電子線線形加速器)がある。LINACを用いると、エネル ギーが高いばかりでなく強度も強くなる。したがって高 い分解能の画像を得ることができる。一方、高エネルギ
一X線は透過力が強いが故に検出が難しいという問題が ある。透過力が強いことは、検出器との相互作用も小さ く、そのまま透過してしまうからである。たとえば $10 \mathrm{M}$ $\mathrm{eV}$ 程度のX線がX線フイルムに当たると、X線光子およそ $10^{5}$ 個に 1 個のみが露光に寄与し、残りの光子はすべて透 過する。つまりこのエネルギ一領域のX線に対するX線 フイルムの量子効率は $10^{-5}$ 程度の極めて小さい值にな る。従って $\mathrm{MeV}$ 領域のX線CTを実現する上での最も重要 な課題は、いかに量子効率の高いX線検出器を用いるか にある。ここでは、LINACをX線源とし、高い検出効率 を実現したシリコン半導体検出器(Si-SSD)をX線検出器 とした高エネルギーX線CTの性能とその応用について 述べる。

\section{2. 産業用X線CTの概要}

\section{1 産業用X線CTの性能因子}

産業用X線CTには、なるべく良好な画質で、なるべく 短時間に、しかもなるべく大きな厚い試料まで撮影した いという要求がある。また鉄などの高密度材料の撮影も できることが望ましい。つまりX線 CTは、分解能・撮影 時間・鉄換算厚さの三つの因子が性能を決定する。ここ で鉄換算厚さとは、どの程度まで厚く密度の高い試料の 撮影ができるかを、鉄の厚さで代表して示すものである。 これら三つの性能因子は互いに梁く関わっており、一つ の性能を高くしようとすれば他の性能因子は犠牲にし なければならないという関係にある。これらの性能因子 は、検出される試料透過後のX線光子数から統一的に論 じることが可能であるがここではそれの定性的な記述 にとどめる。 
断層画像はX線のビーム断面積が小さいほど高分解能 になる。しかしX線光子数はビーム断面積に比例 (場合に よっては断面積の二乗に比例）するので、高い分解能で は光子数が急激に減少する。検出光子数が少ない場合は その統計的摇らぎが相対的に増大し、画質が劣化する。 したがって検出光子数をいかに増やすかに産業用X線CT の課題は集約される。検出光子数を增やすには、X線源の 強度を增す、X線検出器の量子効率を增す、露光時間を増 すの三つの手段がある。ただし露光時間を増すと撮影時 間は長くなり、X線CTの性能が低下することになる。こ れを避けるには検出器の数を増やして単位時間に採取す る透過デー夕数を増やせばよい。それには検出効率を犠 牲にしないで検出器を小さくしなければならない。

\section{2 産業用X線CTの装置構成}

Fig.1にMeV領域X線CTの構成を示す ${ }^{1)}$ 。この装置は X線源としてのLINACと、1次元のX線検出器アレイを対 向して配置し、その間に撮影試料を走查するスキャナが 設置してある。X線源はファンビーム状にX線を放出する ように整形してあり、試料を透過後のファンビームを受 ける位置に検出器アレイが設置してある。試料を回転走 查しながら透過減衰したX線強度を測定する。前節で述べ たようにこの装置の性能はX線源とX線検出器で決まる。

\subsubsection{X線源}

LINACは高いエネルギーまで電子を加速できるが、X 線検查用の線源として用いる場合には、 $12 \mathrm{MeV}$ 程度が上 限と考えるべきである。これ以上エネルギーを高くして もX線透過時の電子対創成の增加により、透過力は頭打ち になるし、中性子発生による遮蔽コストが増大するとい う問題も起きる。X線源として用いるLINACの代表的な 仕様をTable 1に示す。photons $/ \mu \mathrm{Sr} \cdot \mathrm{s} と い う$ 単位は、

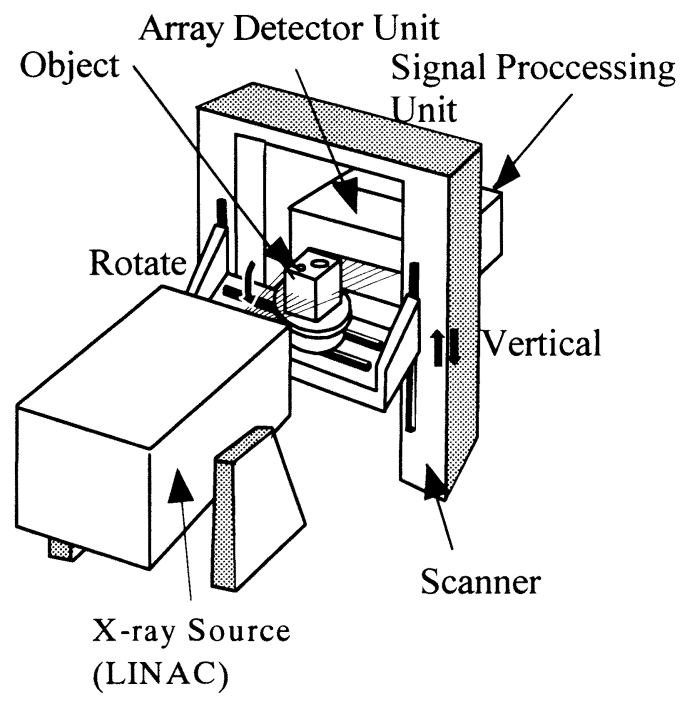

Fig.1 Schema of high energy X-ray CT
Table 1 Specifications of typical LINAC for NDI

\begin{tabular}{|c|c|}
\hline 電子エネルギー & $12 \mathrm{MeV}$ \\
\hline $\mathrm{X}$ 線強度 & $\begin{array}{c}10^{9} \mathrm{photons} \\
/ \mu \mathrm{Sr} \cdot \mathrm{s}\end{array}$ \\
\hline パルスレート & $200 \mathrm{pps}$ \\
\hline パルス幅 & $5 \mu \mathrm{s}$ \\
\hline 焦点サイズ & $0.5 \mathrm{~mm} \phi$ \\
\hline
\end{tabular}

焦点から $1 \mathrm{~m}$ 前方の位置での $1 \mathrm{~mm}^{2}$ に毎秒入射する光子 数である。表に示す值は非破壊検查で通常用いる $300 \mathrm{kV}$ 程度 のX線管のおよそ100倍の光子数である。高い分解 能を得るには線源サイズは小さいほど有利だが、この強 度の高エネルギーX線を得るには $0.5 \mathrm{~mm} \phi$ は一つの限界 と見なさざるを得ない。これ以上サイズを小さくしよう としても、ターゲットが電子線によって瞬間的に加熱さ れ蒸発を起こす。焦点サイズと光子数から決まる輝度は $\mathrm{Co}-60$ などの $\mathrm{RI}$ 線源の $10^{4}$ ないし $10^{5}$ 倍である。

\section{2 .2 X線検出器}

アレイ状に配列したX線検出器と検出器単体をFig.2 に示す2)。試料を透過したX線は、短冊形のSi-SSD
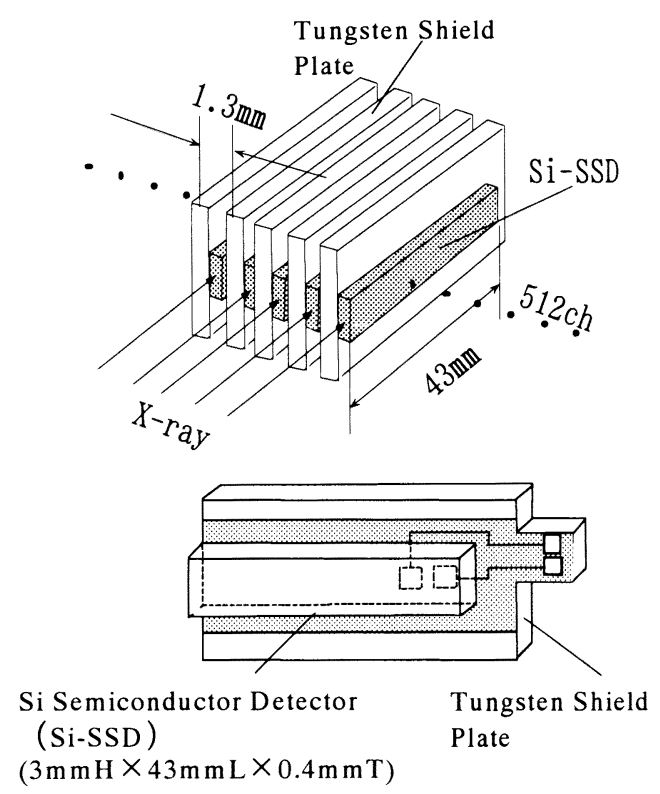

Fig.2 Schema of X-ray detector element.

の小口から長手方向に入射する。この構成により、約 40 $\mathrm{mm}$ のシリコンを透過する間に $20 \%$ ないし $30 \%$ の高エネ ルギーX線光子が検出器と相互作用する。この相互作用 の確率、つまりX線に対する量子効率は、X線フイルム のおよそ3×104倍である。すなわちSi-SSDを使えば、 X 線フイルムの $3 \times 10^{-5}$ 倍のX線量で撮影できる。各検出器 は互いにタングステン板で遮蔽してあり、これにより検 出器相互間のクロストーク（つまり、ある検出器に入射 したX線がそこで散乱して隣接する検出器で検出される 現象で、画像劣化の原因になる）を防止する。半導体検 
出器は小型で狭いピッチでの多数配列ができるので単位 時間に多数の透過データが採取できる点でシンチレータ よりも有利である。なお最近はSi-SSDよりも高い検出効 率が得られる化合物半導体 $(\mathrm{GaAs})$ のX線検出器も開発 されつつある ${ }^{3)}$ 。これが実用化すれば、 $\mathrm{MeV}$ 領域X線を $50 \%$ 以の量子効率で検出でき、画質はさらに向上する。

\section{X線CTの限界性能}

第2章で述べたように、CTの性能は、検出されるX線光 子数でほぼ決まる。しかしそこには前提がある。光子数 の統計的な変動以外に雑音のないことである。X線検出信 号には各種の雑音が混入する。雑音の主なものには、散 乱線、クロストーク、検出器漏洩電流、電子回路系の各 種ドリフトや電磁雑音などがある。これらをゼロにする ことは原理的に困難ではあるが、無視できる程度まで低 減することは可能である。無視できる程度とは、光子の 統計的摇らぎ比較してこれらの雑音が十分小さいこと である。これらの雑音のうち、散乱線は一次元アレイセ ンサを使う限り無視できる。これは、使用するビーム形 状がコーン状ではなくファン状であることが幸いしてい る。ファンビームの厚さが薄くなれば検出器に入る被検 体からの散乱線はゼロに近づく。クロストークは検出器 と検出器の間に遮蔽版を設置することで無視できるレべ ルにすることが可能である。検出器の漏洩電流は検出器 自体の性能にとって重要だが、これも現在は、検出され る $\mathrm{MeV}$ 領域X線光子 0.1 個に相当する程度まで低減できて いる。電磁雑音で最も問題になるのはLINACが発生する 電磁波であるが、十分な遮蔽により無視できるレベルま で低減できる。これらの雑音のすべてを総合しても現在 では検出されるX線光子 1 個以下に低減することは可能で ある。従ってX線光子の統計的摇らぎのみが画質決定要因 と考えて差し支えない。なお、X線検出にシンチレータと 光電子増倍管を組み合わせたり、イメージインテンシフ アイア（II）のように蛍光体で発生した光を増幅する手 段があるが、これらの二次電子増幅や光増幅は、透過し たX線光子の統計的摇らぎを增加する方向に働き、低減す る機能を持つものではない。これらの增幅は電子回路系 の雑音を相対的に低減することが目的である。さて、こ のようなレベルまで雑音を低減した場合に、どうしても 回避できない雑音として残るものがX線光子の統計的ば らつき（摇らぎ）である。この摇らぎは検出できるX線光 子数の平方根に比例する。たとえば 104 個の光子を検出す れば、その平方根である $10^{2}$ 個つまり $1 \%$ 不確定性が存 在することになる。102個の光子を検出したならばその不 確定性は10\%になる。この不確定性を低減するには、検 出されるX線光子数を増加する以外に手段はない。単位 時間あたりの検出光子数を増加する手段には、X線源の強 度を增すこととX線検出器の検出効率を増すことの二つ
Table 2. Relation between X-ray photons and beam cross section

\begin{tabular}{|c|c|}
\hline ビーム太さ $\left(\mathrm{mm}^{2}\right)$ & 入射光子数 $\left(\mathrm{s}^{-1}\right)$ \\
\hline $0.1 \times 0.1$ & $4 \times 10^{5}$ \\
\hline $0.2 \times 0.2$ & $6.4 \times 10^{6}$ \\
\hline $0.5 \times 0.5$ & $2.5 \times 10^{8}$ \\
\hline $1.0 \times 1.0$ & $1 \times 10^{9}$ \\
\hline $2.0 \times 2.0$ & $4 \times 10^{9}$ \\
\hline $5.0 \times 5.0$ & $2.5 \times 10^{10}$ \\
\hline
\end{tabular}

があり、それ以外にはない。すなわち、X線光子の統計 的摇らき以外の雑音を十分に低減した装置において、そ の性能はX線源の性能と検出器の性能ですべてが決まる。 Table 1に示した性能のX線源から $1 \mathrm{~m}$ の位置に検出器が あるとした場合に検出器に入射する1秒あたりの光子数 をビーム断面積 (分解能に対応) とともにTable 2 に示 す。ビーム断面積が $0.5 \mathrm{~mm} \times 0.5 \mathrm{~mm}$ 以上ではX線光子数 はビームの断面積に比例するが、 $0.5 \mathrm{~mm} \times 0.5 \mathrm{~mm}$ 以下で はその関係が崩れて、 $0.2 \mathrm{~mm} \times 0.2 \mathrm{~mm}$ 以下ではビーム断 面積の二乗に比例して光子数は急激に減少する。これは $\mathrm{X}$ 線源の焦点サイズが有限の大きさを持つことにより 起こる現象である。焦点サイズがTable 1に示す值より 小さくなれば、狭险ビームの場合の光子数はTable 2 の 值より増加する。LINACのパルスレートに検出器の数 (チヤンネル数) を乗じると1秒あたりに採取できるデ 一夕数が決まる。検出器の数を 500 チャンネルと想定し た場合には、1秒あたり $10^{5}$ 個のデー夕が採取できる。画 素数を $1000 \times 1000$ とすれば、必要なデー夕数は約 $10^{6}$ 個 であるから、約 10 秒でデー夕採取が完了する。つまり撮 影時間は10秒になる。ただし先に述べた光子の統計的ば らつきが大きい場合、すなわち高い分解能を要求したり 減衰の大きな厚い材料を撮影する場合には、それに応じ て撮影時間を長くして画質を保持することになる。これ らを考慮すると、Table 1に掲げた仕様のX線源と、500 チャンネルの半導体検出器を組み合わせた場合には $\mathrm{Tab}$ le 3に示すような条件で撮影が可能である。

Table 3. Data acquisition time of CT(s)

\begin{tabular}{|c|c|c|c|c|c|c|}
\hline \multicolumn{2}{|c|}{} & \multicolumn{5}{|c|}{ 鉄換算厚さ $(\mathrm{mm})$} \\
\cline { 2 - 7 } \multicolumn{2}{c|}{} & 100 & 200 & 300 & 400 & 500 \\
\hline \multirow{4}{*}{\begin{tabular}{c} 
分 \\
解 \\
能 \\
\cline { 2 - 7 }
\end{tabular}} & 0.1 & 20 & - & - & - & - \\
\cline { 2 - 8 } & 0.2 & 10 & 10 & 20 & - & - \\
\cline { 2 - 8 } & 0.5 & 10 & 10 & 10 & 20 & - \\
\cline { 2 - 8 } & 1.0 & 10 & 10 & 10 & 10 & 100 \\
\cline { 2 - 8 } & 2.0 & 10 & 10 & 10 & 10 & 20 \\
\cline { 2 - 8 } & 5.0 & 10 & 10 & 10 & 10 & 10 \\
\hline
\end{tabular}




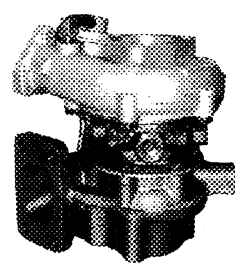

実物
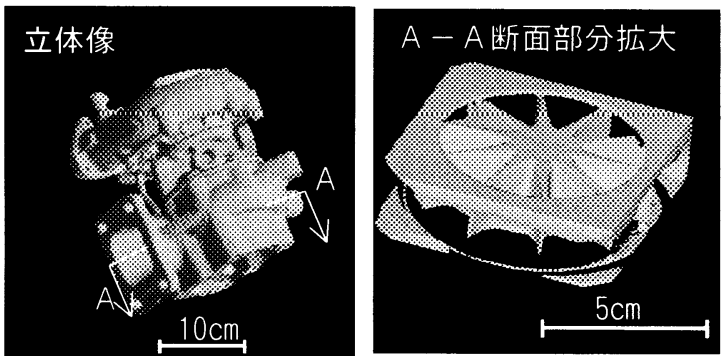

Photo.1 2D and 3D Images of turbo-charger for automobile.

この表で「一」で示してある箇所は撮影時間が非現実的 に長くなり、実用上撮影が不可能なことを示す。鉄換算 厚が $100 \mathrm{~mm}$ の場合でも $0.1 \mathrm{~mm}$ の分解能での撮影は光子 数が不足し、20秒程度の撮影時間が必要である。とはい え広い条件範囲で 10 秒の撮影時間が可能であり、しかも 5 $00 \mathrm{~mm}$ までの鉄厚（アルミニウムならば $1500 \mathrm{~mm}$ 程度ま で）の撮影が短時間で可能で、医療用に比較して格段に 高い分解能が得られることは、LINACの高い能力と高い 量子効率を持つX線検出器により初めて実現できるもの である。

\section{4. 高エネルギーX線CTの応用}

X線CTにより多断層撮影した結果を三次元表示した例 をphoto.1およびphoto.2に示す。これらは6MeVのLINA $\mathrm{C}$ を $\mathrm{X}$ 線源とし、断層面上の分解能 $0.2 \mathrm{~mm}$ 、スライス厚 さ $1 \mathrm{~mm}$ の条件で撮影したものである。また立体画像は断 層像の $5 \times 5$ の画素を一つの画素に縮退して表示してある。 高エネルギーX線CTの利用により、透過厚が $1 \mathrm{~m}$ を越える 大型でしかも高密度な試料を、 $1000 \times 1000 な い し 3000$ $\times 3000$ 程度の画素をもつ高分解能な断層像または透過像 として撮影できるようになり、その応用範囲は飛躍的に 拡大することが期待される。考古学や古生物学の分野で は、発掘されたアンモナイトの化石やネアンデルタール 人の頭骨の $0.1 \mathrm{~mm}$ の精度を持つ完全な三次元復元画像や、 それに基づいて光造形法によって製作された完全なレプ リカを世界中の研究者に配布したり博物館に展示するこ とも可能になる。また、自動車などの機械産業では3D-C $\mathrm{ADが}$ 普及しつつあり、設計図とその製造物を三次元空間 上で比較することも可能になる。このように数百ないし 数千枚の断層写真から 3 次元画像を計算機上に構築する
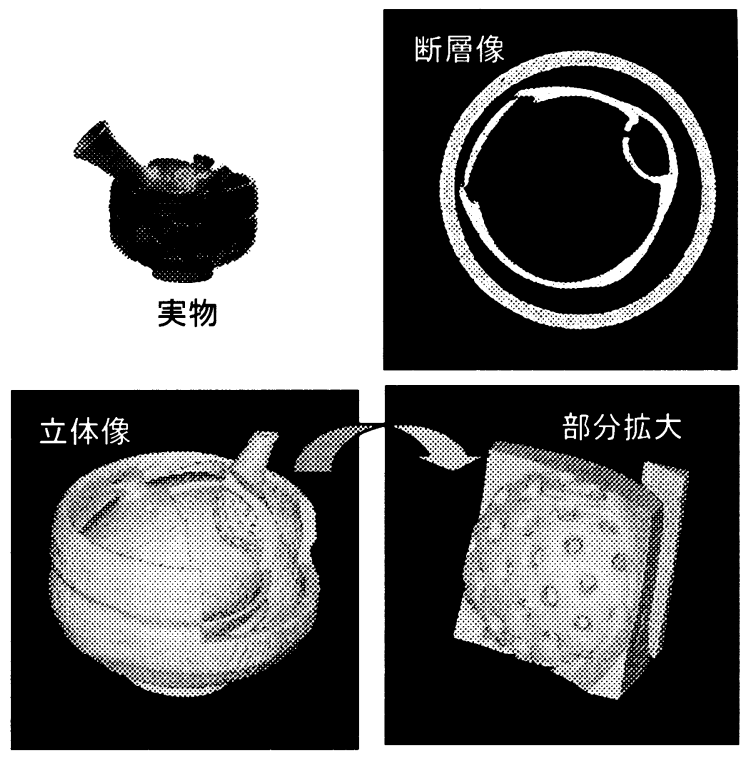

Photo.2 2D and 3D Images of tea pot and tea bowl.

ことは、今後の機械系3D-CADの有効活用に不可欠の技 術になる。

\section{5. おわりに}

高エネルギーX線CTは、その利用が緒についたばかり である。その利用が拡大するに従い、試料の、ある特定 の断面一枚の撮影をすることから、数百ないし数千枚の 断層撮影により試料全体の立体画像を計算機内に再現 することへとニーズが拡大しつつある。この場合には一 枚あたりの撮影時間を短くすることがとくに切実な問 題になる。撮影時間はX線検出器の数に逆比例するので、 なるべく多数の検出器を稠密に配列した方がよい。それ には検出器を量子効率を低下せずに小型化しなければ ならない。この辺の開発課題は未だ残っていると考える。 しかし理想的な検出器ができたとしても、それによる改 善で向上できる性能は数倍までである。つまり $\mathrm{MeV}$ 領域 のX線CTの性能はその理論的限界に近づきつつあり、今 後はむしろ精密な断層像・透過像をいかにうまく利用す るかのソフトウエアの開発が重要になると考える。

\section{参 考 文 献}

[1] H.Miyai,et.al. ; 1996 Nucl. Sci. Symp., Conference Record Vol.2 pp.816-821(1997)

[2] H.Miyai,et.al. ; Nucl. Sci. and Meth. A353 pp.97-100.(1994).

[3] 北口博司 他 ; 日本原子力学会「1998年秋の大会」 $\mathrm{B} 42$. 